\title{
Roles of Leadership Styles in Corporate Social Responsibility to Non- Governmental Organizations (NGOs)
}

\author{
Ahmet Demir ${ }^{1} \&$ Taylan Budur ${ }^{2}$ \\ $1 \& 2$ Tshik International University, Sulaimani, Iraq \\ Correspondence: Ahmet Demir, Tshik International University, Sulaimani, Iraq. \\ Email: ahmet.demir@ishik.edu.iq \\ Received: April 10, 2019 \\ Accepted: May 24, 2019 \\ Online Published: June 1, 2019 \\ doi: 10.23918/ijsses.v5i4p174

\begin{abstract}
This study aims to investigate the interplay between leadership styles and institutional corporate social responsibility (CSR) practices with non-governmental organizations (NGOs). Field survey of employee's reveals that firms with greater ethical leadership are more likely to engage in institutional CSR practices with NGOs, whereas transformational leadership is associated relatively less with such practices. This research highlights the differential roles that ethical and transformational leadership styles play for a firm's institutional CSR practices with NGOs and has significant implications for theory and practice.
\end{abstract}

Keywords: Corporate Social Responsibility, NGO, Ethical Leadership, Transformational Leadership

\section{Introduction}

Corporate social responsibility, as "the broad array of strategies and operating practices that a company develops in its efforts to deal with and create relationships with its numerous stakeholders and the natural environment" (Waddock 2004, p. 10), is an emerging issue all around the world. Already thousands of corporations from hundreds of countries have been cooperating with United Nations policies in order to keep socially responsible corporation (Du et al., 2013). Besides, researchers hasn't paid sufficient attention yet how ethical leadership plays an important role in CSR practices with NGOs. This study from this point investigates the roles of leadership styles in CSR practices with NGOs.

Leadership is accepted as one of the most influential factors on the employees to boost their performance in the organizations (Pradeep \& Prabhu, 2011; Shafie et al., 2013; Torlak \& Kuzey, 2019). Besides, leaders are the inspirational role models to create awareness and to increase acceptance of the company's objectives (Dess \& Robinson, 1984). Stogdill (1950) noted leadership as influencing process of employees to reach organizational objectives.

Because of its crucial role on the effectiveness of the organization, scholars have always focused on the attitudes and behaviors of the successful leaders (Ivancevich et al. 1990; Walumbwa and Lawler, 2003; Yuk1, 2008). They tried to find out leaders' common traits or behaviors that provide them this potential to foster employee's performance (Colbert et al., 2012; Derue et al., 2011). In this context, firstly academicians accepted that leaders are born not made (Borgatta et al., 1954; Gehring, 2007). Following this further, it is demonstrated that for being a leader these traits must come from the ancestors and must be placed in DNAs (Hutchens, 2015). Second, the studies of the Ohio state and Michigan University 
focused on the situational circumstances that affect leaders' behaviors. They mainly asserted that leaders represent job-oriented and employee-oriented behaviors in the organization (Certo \& Certo, 2011, p. 390400). Further, Vecchio et al., (2006) noted successful of the leadership (SL) depends on three main factors, which are Followers (F), Leaders (L) behaviors and Situation (S) (illustrated as; SL: F, L, S). This theory could be simplified as leader's effectiveness occurs only in the correct circumstances and by the correct employees. Further, Stogdill (1948) summarized some of the strong characteristics of successful leaders as follows; their intelligence, emotional maturity and consistency, participation to social activities and groups and their desire to achievements (Certo \& Certo, 2011 pp. 390-395). In contrast Moten (2011) asserted that there isn't one best style of leadership that is going to be victories in all kinds of organizations or circumstances. Furthermore, in the last two decades Fiedler's contingency approach (Chemers, 2000) and Evans's path-goal theory (Evans, 1996; Budur, 2018) improved along with the leadership studies. Finally, modern management accept that leadership traits and behaviors should be gained and improved through education and trainings in contrast to Great Men theory (Bass, 1990; Yukl, 2002). In this respect, current literature provides enough studies about the modern leadership theories, which are transformational leadership, transactional leadership, servant leadership, ethical leadership, authentic leadership and virtue-based leadership.

There are some studies which investigate the roles of leadership styles to CSR practices in general. For example, Waldman et al. (2006) have tested the impact of transformational leadership (excluding the charisma dimension) on the CSR practices of the firms. Trong (2012) examined leadership styles and CSR principals according to Carrol (1979) theory and noted while transactional leadership is correlated with legal and economic side of CSR, transformational leadership is relatively associated with the ethical side of the CSR activities that cause brand equity in turn. Another research in this field has been studied by Du et al. (2013) by investigating the roles of leadership styles in CSR practices in corporations. They have found that transformational leadership had significant impact on the CSR practices while transactional leadership didn't. Further, Mazutis and Zintel (2015) empirically revealed that leadership has direct, indirect and moderative effect on the social responsibilities of the organization. Besides, DiSegni et al. (2015) noted effective management and active social responsibility of the organizations positively correlated with the financial performance. And Alonso Almeida et al. (2017) investigated gender and leadership styles differences for CSR practices of organizations in Spain and found that transformational leadership and females are more tended to be effective in CSR activities, while dominance leadership was the lowest level of leadership style for the CSR of the company. Similarly, Lin and Liu (2017) noted ethical leadership moderates the relationship between CSR and work engagement in the workplace. Furthermore, some studies have found that ethical leadership have positive effects on socially responsible activities of the organizations (De Hoogh \& Den Hartog, 2008; Mazutis \& Zintel, 2015) but empirical studies in this field should investigate these effects further and in detail. For this reason, this study aims to investigate how ethical and transformational leadership styles affects the firm's CSR practices, specifically with the NGOs. From this point of view, the study closes a gap and contributes an important research to the organizational leadership literature due to little is known about those relationships and especially how ethical leadership affects organizations strategies and employees' attitudes about the social activities with NGOs.

The study has been divided into five sections. In the first section, named as introduction, we have introduced the main research problem. In the second section, we have drawn a theoretical background 
which elaborates the previous studies in this field. In the third section, methodology of the study has been explained. In the fourth section, data analysis and hypothesis testing has been proposed. Finally, in the fifth section, conclusions has been stated a long with discussing the previous studies.

\section{Literature Review}

\subsection{Corporate Social Responsibility}

Guarnieri and Kao (2008) defined CSR as "the continuing commitment by business to behave ethically and contribute to economic development while improving the quality of life of the workforce and their families as well as the local community and society at large." For Aguinis and Glavas (2012), CSR involves the social activities of the organizations among organizations, employees and public. In the light of these definitions, this study accepts Türker's (2009) definition about CSR and explains it as the company's and employees' support to non-governmental activities in the market.

CSR activities may increase the awareness of the firms in the public and cause extra performance in the organization and attract more customer from the market. But for Friedman (2007) managers' have to be strategic while using the resources of the company for the sake of the public, which cannot provide extra profit for the organization. He asserted that the reason of the existence of any organization is to maximize the shareholders' profit. Conversely, scholars noted to prevent any conflict among the stakeholders (who are affected by the activities of the organization; customers, suppliers, governmental agencies, financial institutions and local organizations etc.) an optimum level of using or acting social activities in the market (Freeman et al., 2004; Jensen, 2001; McWilliams \& Siegel, 2001). According to Waldman et al. (2006) this optimum could be clarified through strategic cost and benefit assessments. This evaluation defined as stakeholder theory, which means the win to win process of while company increase its profit, stakeholders must be satisfied in long term through these activities as well (Freeman, 1999).

\subsection{Transformational Leadership}

Transformational leadership was firstly defined by Burns (1978) as the process of interrelated effects between leader and followers to increase their motivation and moral in the organization. Bass (1990) noted, "Transformational leadership occurs when leaders broaden and elevate the interests of their employees, when they generate awareness and acceptance of the purposes and mission of the group, and when they stir their employees to look beyond their own self-interest for the good of the group."

Further, Bass (1990) mentioned some specialties of Transformational leaders namely; as being role model with charisma to their followers, their individual mentorship in the organization to foster career development, their encouragement to employees to find better ways for the problems of the organization and their inspiration to represent extra effort for the organizational objectives.

Mazutis and Zintel, (2015) revealed that leadership is an important factor to follow socially responsible activities in the organization. Šarotar et al. (2017) put forward that transformational leaders are the cause of healthy and satisfied employees in the work place that promote staffs and organizations social responsiveness for the country. Allen et al. (2017) noted transformational leaders increase employee's perception about the company's social responsibilities and this perception fosters staff's organizational identification and commitment. Similarly, Waldman et al. (2006) found that transformational leadership 
has a positive effect on firm to act social activities. Additionally, they noted while there isn't any significant association between charisma and CSR, intellectual stimulation is positively and significantly correlated with CSR activities.

\subsection{Ethical Leadership}

Ethical leadership is defined as ethical leadership as "the demonstration of normatively appropriate conduct through personal actions and interpersonal relationships, and the promotion of such conduct to followers through two-way communication, reinforcement, and decision making" (Brown et al., 2005). Kanungo (2011) noted ethical leadership as leaders' virtues behaviors or conduct in the organization that others can make profit through these behaviors as well. Besides that, Trevino et al. (2003) pointed out that ethical leaders act as honest, reliable, attentive and fair as their main characteristics. Additionally, ethical leaders are not only preacher of virtues they are the main characters of the ethical values in the organization (Dinc \& Nurovic, 2016).

Further, the current literature does not provide enough evidence that explains the connection between ethical leadership and CSR to NGOs. Some of the similar studies could be summarized as; Vitell et al. (2004) proposed that clear ethical rules in the work place increase employees CSR perception. Zhu et al. (2013) found that ethical leadership moderate the indirect relationship of CSR between reputation and firm performance. Similarly, Wu et al. (2015) noted a positive significant indirect relationship between ethical leadership and CSR over ethical culture.

\section{Methodology}

The sample used for this study was 197 employees from around 50 private firms in Sulaimani, Kurdistan Region of Iraq. Based on the education information of the participants, 1.5 percent of them were $\mathrm{PhD}$ holder, 18.8 percent were master degree holder, 75.6 percent were bachelor degree holder, and 4.1 percent of them were secondary school degree holder. Moreover, it has been observed among the participants that 4.1 percent had experience less than one year, 33 percent had experience between 1-5 years, 41.6 percent of them had experience between 6-10 years, 3 percent of them had experience between 11-15 years, and 18.3 percent of the sample population had experience between 15 years and above. Please see Table 1 and 2 for the further details. Originally 500 copies of questionnaire have been distributed as hard copy to randomly selected employees at each organization but only 197 of them has been returned. So that the return rate is 39 percent. Finally, 197 data have been remained to continue with further analysis.

Table 1: Education level of sample population

\begin{tabular}{lcccc}
\hline & Frequency & Percent & Valid Percent & $\begin{array}{c}\text { Cumulative } \\
\text { Percent }\end{array}$ \\
\hline PhD & 3 & 1.5 & 1.5 & 1.5 \\
\hline Master & 37 & 18.8 & 18.8 & 20.3 \\
\hline University & 149 & 75.6 & 75.6 & 95.9 \\
\hline $\begin{array}{l}\text { Secondary } \\
\text { School }\end{array}$ & 8 & 4.1 & 4.1 & 100.0 \\
\hline Total & 197 & 100.0 & 100.0 & \\
\hline
\end{tabular}


The questionnaire of this study was adopted from the various studies. The questionnaire includes four dimensions such as ethical leadership (10 questions), transformational leadership (12 questions), and corporate social responsibility of firm toward NGOs in Kurdistan Region of Iraq (3 questions).

Table 2: Job experience of sample population

\begin{tabular}{lcccc}
\hline & Frequency & Percent & $\begin{array}{c}\text { Valid } \\
\text { Percent }\end{array}$ & Cumulative Percent \\
\hline Less than 1 Year & 8 & 4.1 & 4.1 & 4.1 \\
\hline $1-5$ years & 65 & 33.0 & 33.0 & 37.1 \\
\hline $11-15$ years & 6 & 3.0 & 3.0 & 40.1 \\
\hline 6 - 10 years & 82 & 41.6 & 41.6 & 81.7 \\
\hline More than 15 years & 36 & 18.3 & 18.3 & 100.0 \\
\hline Total & 197 & 100.0 & 100.0 & \\
\hline
\end{tabular}

Respondents were asked to rate their perceptions for each question. Each question was rated based on the Likert scale that ranged from 1 (strongly disagree) to 5 (strongly agree). The questions were both in Kurdish and in English which were translated by an expert who was a member of academic staff in English language teaching department of Tishk International University (formerly known as Ishik University).

The obtained data was analyzed by using IBM SPSS 24 and IBM AMOS 23. Initially, reliability and validity analysis have been proposed to prove the appropriateness of the collected data. For reliability, Cronbach's Alpha test was performed and, for validity, confirmatory factor analysis (CFA) was conducted. Secondly, structural equations modeling has been proposed to indicate the impact of ethical leadership and transformational leadership on the corporate social responsibility of the firms toward NGOs in the region. Please see Figure 1 for the further details.

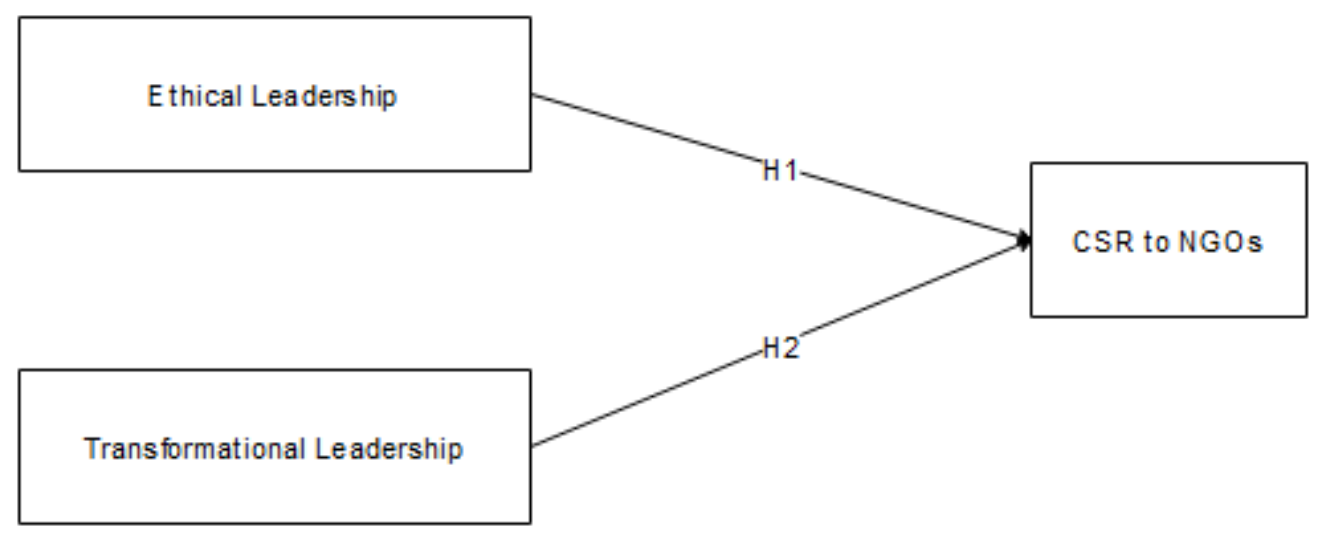

Figure 1: Model of the Study 


\section{Data Analysis and Findings}

\subsection{Reliability and Validity Analysis}

In this section, Cronbach's alpha level of each dimension has been indicated in order to test internal validity of survey questionnaire. It has been observed that transformational leadership dimension ranged as 0.961 , ethical leadership as 0.945 , and CSR to NGOs dimension as 0.923 . These results showed that reliability of the constructs was met.

Secondly, in order to test the validity further, confirmatory factor analysis has been proposed. Comparative and absolute model fit values were tracked. It was observed that comparative fit indexes such as CFI (0.94) and Trucker-Lewis' coefficient (TLI, 0.93) were above the threshold values (Olobatuyi, 2006). Furthermore, concerning absolute fit indexes, chi-square $(\mathrm{X} 2,2.142)$, root mean square error of approximation (RMSEA, 0.083), good fit index (GFI, 0.83), and adjusted good fit index (AGFI, 0.81) were also at the acceptable levels (Marsh \& Hocevar, 1988; Byrne, 2013).

Table 3 Discriminant and Convergent Validities

\begin{tabular}{lccccc}
\hline & CR & AVE & TL & EL & NGO \\
\hline TL & 0.963 & 0.685 & $0.828^{\mathrm{a}}$ & & \\
\hline EL & 0.957 & 0.688 & $0.815^{\mathrm{b}}$ & 0.830 & \\
\hline NGO & 0.853 & 0.659 & 0.580 & 0.678 & 0.812
\end{tabular}

CR: composite reliability, AVE: Average variance extracted, a: Square root of average variance extracted in bold, b: Correlation coefficients not in bold.

As a next step, discriminant and convergent validity has been tested. These tests were employed in order to find out whether the constructs kept the sufficient distance from each other (discriminant validity) and had sufficient closeness of each item to other items under the same construct (convergent validity) (Khine, 2013). Discriminant validity was achieved due to all square root of average variance extracted were above the correlation coefficients of other dimensions.

Convergent validity was also assessed by average variance extracted (AVE) holding threshold value minimally 0.5 and composite reliability (C.R.) holding minimal value 0.7 (Fornell \& Larcker, 1981). For the further details please see Table 3.

\subsection{Measurement Model Analysis}

In this section, we have tested the hypothesis those have been claimed in the previous sections. To do this, structural equations modeling was developed from ethical leadership, transformational leadership, and CSR to NGOs constructs. Due to the designed model, impact of transformational leadership and ethical leadership on CSR to NGOs have been tested. 
Structural equations modeling (SEM) has tested direct and indirect effects of ethical and transformational leadership variables on CSR to NGO. As model of SEM, maximum likelihood was engaged. Table 4 illustrates the results of direct effects. It has been observed that both ethical leadership $(\beta=0.766, t=$ 11.361, $\mathrm{p}<0.01)$ and transformational leadership $(\beta=0.207, \mathrm{t}=3.550, \mathrm{p}<0.01)$ had a significant positive impact on CSR to NGOs. Thus, $\mathrm{H} 1$ and $\mathrm{H} 2$ have been accepted.

Table 4: Results of hypothesis

\begin{tabular}{cccccccr}
\hline Hypothesis & $\begin{array}{c}\text { Dependent } \\
\text { Variable }\end{array}$ & & $\begin{array}{c}\text { Independent } \\
\text { Variable }\end{array}$ & Estimate & S.E. & P & H.R. \\
H1 & NGO & $<---$ & EL & 0.766 & 0.075 & $* * *$ & Accepted \\
\hline H2 & NGO & $<---$ & TL & 0.207 & 0.061 & $* * *$ & Accepted \\
\hline $\mathrm{X} 2 / \mathrm{DF}=1.994 ; \mathrm{RMR}=0.051 ; \mathrm{RMSEA}=0.063 ; \mathrm{CFI}=0.910 ; \mathrm{TLI}=0.921 ; \mathrm{GFI}=0.871 ;$ AGFI $=$ \\
0.822
\end{tabular}

Note: S.E.: Standard error; P: Significance level; H.R.: Hypothesis result

\section{Discussion and Conclusion}

This research has been studied to understand the impacts of leadership styles on the CSR practices of the firms with NGOs. To do this, we have collected data from around 200 employees of different companies and asked them questions to fill. The obtained data has been analyzed by proposing structural equations modeling.

Waldman et al. (2006) have found positive impact of transformational leadership on the CSR practices of the organizations. Similarly, this Du et al. (2013) have also found the same significant impact. However, the current study supported the suggestions of the previous researchers from this point and we also suggest that the transformational leadership has significant impact on the CSR practices of the firms with NGOs. Based on some studies (De Hoogh \& Den Hartog, 2008; Mazutis \& Zintel, 2015), ethical sides of the leadership styles have significant impact on the CSR practices of the firms. Similarly, the current study also supports that the ethical leadership has significant impact on the CSR practices of the firms with NGOs.

The results of the current study show that both transformational leadership and ethical leadership had significant impact on the CSR practices of the firms with NGOs. Besides, it can be revealed from the hypothesis results that ethical leadership had stronger positive impact on the CSR practices of the firms with NGOs rather than transformational leadership. The reason behind this might be that the ethical leaders care about the social and ethical rules which is strongly tied with the CSR practices. The CSR practices are thought to be affecting the financial performance of the organizations. Based on these results, we suggest firms to hire ethical leaders or managers who would manage firms ethically, would increase the practices in CSR with NGOs, in return, will impact the organizations financial return positively.

There are some limitations of the study. Initially, the number of data which has been used in this study is limited. Further, it scopes only private institutions of Sulaimani, Kurdistan Region of Iraq. It cannot be generalized to all region. To be more generalized, the further studies must consider collecting data from other private institutions of Kurdistan region of Iraq. 


\section{References}

Aguinis, H., \& Glavas, A. (2012). What we know and don't know about corporate social responsibility: A review and research agenda. Journal of Management, 38(4), 932-968.

Allen, G. W., Attoh, P. A., \& Gong, T. (2017). Transformational leadership and affective organizational commitment: mediating roles of perceived social responsibility and organizational identification. Social Responsibility Journal, 13(3), 585-600.

Alonso Almeida, M. D. M., Perramon, J., \& Bagur- Femenias, L. (2017). Leadership styles and corporate social responsibility management: Analysis from a gender perspective. Business Ethics: A European Review, 26(2), 147-161.

Bass, B. M. (1990). From transactional to transformational leadership: Learning to share the vision. Organizational Dynamics, 18(3), 19-31.

Borgatta, E. F., Bales, R. F., \& Couch, A. S. (1954). Some findings relevant to the great man theory of leadership. American Sociological Review, 19(6), 755-759.

Brown, M. E., Treviño, L. K., \& Harrison, D. A. (2005). Ethical leadership: A social learning perspective for construct development and testing. Organizational Behavior and Human Decision Processes, 97(2), 117-134.

Budur, T. (2018). The impact of Al-Ghazali's virtues on organizational commitment and performance: A case Study at private education institutions in Kurdistan Region of Iraq. ICABEP, Erbil-Iraq, Vol.2, p21.

Burns, J. M. (1978). Leadership. New York: Harper Row.

Carroll, A. B. (1979). A three-dimensional conceptual model of corporate performance. Academy of Management Review, 4(4), 497-505.

Certo, S. C., \& Certo, S. T. (2011). Modern Management Concepts and Skills. New Jersey: Prentice Hall

Chemers, M. M. (2000). Leadership research and theory: A functional integration. Group Dynamics: Theory, research, and practice, 4(1), 27.

Colbert, A. E., Judge, T. A., Choi, D., \& Wang, G. (2012). Assessing the trait theory of leadership using self and observer ratings of personality: The mediating role of contributions to group success. The Leadership Quarterly, 23(4), 670-685.

De Hoogh, A. H., \& Den Hartog, D. N. (2008). Ethical and despotic leadership, relationships with leader's social responsibility, top management team effectiveness and subordinates' optimism: A multi-method study. The Leadership Quarterly, 19(3), 297-311.

Derue, D. S., Nahrgang, J. D., Wellman, N. E. D., \& Humphrey, S. E. (2011). Trait and behavioral theories of leadership: An integration and meta- analytic test of their relative validity. Personnel Psychology, 64(1), 7-52.

Dess, G. G., \& Robinson Jr, R. B. (1984). Measuring organizational performance in the absence of objective measures: the case of the privately held firm and conglomerate business unit. Strategic Management Journal, 5(3), 265-273.

Dinc, M. S., \& Nurovic, E. (2016). The impact of ethical leadership on employee attitudes in anufacturing companies. Nile Journal of Business and Economics, 2(3), 3-14.

DiSegni, D. M., Huly, M., \& Akron, S. (2015). Corporate social responsibility, environmental leadership and financial performance. Social Responsibility Journal, 11(1), 131-148.

Du, S., Swaen, V., Lindgreen, A., \& Sen, S. (2013). The roles of leadership styles in corporate social responsibility. Journal of Business Ethics, 114(1), 155-169.

Evans, M. G. (1996). RJ House's “A path-goal theory of leader effectiveness". The Leadership Quarterly, 7(3), 305-309.

Freeman, R. E. (1999). Divergent stakeholder theory. Academy of Management Review, 24(2), 233-236.

Freeman, R. E., Wicks, A. C., \& Parmar, B. (2004). Stakeholder theory and "the corporate objective revisited". Organization science, 15(3), 364-369. 
Friedman, M. (2007). The social responsibility of business is to increase its profits. In Corporate ethics and corporate governance (pp. 173-178). Springer, Berlin, Heidelberg.

Gehring, D. R. (2007). Applying traits theory of leadership to project management. Project Management Journal, 38(1), 44-54.

Guarnieri, R., \& Kao, T. (2008). Leadership and CSR-a perfect match: How top companies for leaders utilize CSR as a competitive advantage. People and Strategy, 31(3), 34.

Hutchens, C. (2015). Look at your ancestors to discover your character! Leading the Way, 12(2), 18.

Ivancevich, J. M., Matteson, M. T., \& Konopaske, R. (1990). Organizational behavior and management.

Jensen, M. C. (2001). Value maximization, stakeholder theory, and the corporate objective function. Journal of Applied Corporate Finance, 14(3), 8-21.

Kanungo, R. N. (2001). Ethical values of transactional and transformational leaders. Canadian Journal of Administrative Sciences/Revue Canadienne des Sciences de l'Administration, 18(4), 257265

Lin, C. P., \& Liu, M. L. (2017). Examining the effects of corporate social responsibility and ethical leadership on turnover intention. Personnel Review, 46(3), 526-550.

Mazutis, D., \& Zintel, C. (2015). Leadership and corporate responsibility: A review of the empirical evidence. Annals in Social Responsibility, 1(1), 76-107.

Mazutis, D., \& Zintel, C. (2015). Leadership and corporate responsibility: A review of the empirical evidence. Annals in Social Responsibility, 1(1), 76-107.

McWilliams, A., \& Siegel, D. (2001). Corporate social responsibility: A theory of the firm perspective. Academy of Management Review, 26(1), 117-127.

Moten, A. R. (2011). Leadership in the West and the Islamic World: A Comparative Analysis. World Applied Sciences Journal, 339-349

Pradeep, D. D., \& Prabhu, N. R. V. (2011). The relationship between effective leadership and employee performance. In International Conference on Advancements in Information Technology (Vol. 20, pp. 198-207).

Šarotar Žižek, S., Mulej, M., \& Veingerl Čič, Ž. (2017). Results of socially responsible transformational leadership: increased holism and success. Kybernetes, 46(3), 400-418.

Shafie, B., Baghersalimi, S., \& Barghi, V. (2013). The relationship between leadership style and employee performance: Case study of real estate registration organization of Tehran Province. Singaporean Journal of Business, Economics and Management Studies, 51(1119), 1-9.

Stogdill, R. M. (1948). Personal factors associated with leadership: A survey of the literature. The Journal of Psychology, 25(1), 35-71.

Stogdill, R. M. (1950). Leadership, membership and organization. Psychological Bulletin, 47(1), 1.

Torlak, N. G., \& Kuzey, C. (2019). Leadership, job satisfaction and performance links in private education institutes of Pakistan. International Journal of Productivity and Performance Management, 68(2), 276-295.

Trevino, L. K., Brown, M., \& Hartman, L. P. (2003). A qualitative investigation of perceived executive ethical leadership: Perceptions from inside and outside the executive suite. Human Relations, $56,5-37$.

Trong Tuan, L. (2012). Corporate social responsibility, leadership, and brand equity in healthcare service. Social Responsibility Journal, 8(3), 347-362.

Turker, D. (2009). Measuring corporate social responsibility: A scale development study. Journal of Business Ethics, 85(4), 411-427.

Vecchio, R. P., Bullis, R. C., \& Brazil, D. M. (2006). The utility of situational leadership theory: A replication in a military setting. Small Group Research, 37(5), 407-424.

Vitell, S. J., \& Paolillo, J. G. (2004). A cross cultural study of the antecedents of the perceived role of ethics and social responsibility. Business Ethics: A European Review, 13(2- 3), 185-199.

Waddock, S. (2004). Parallel universes: Companies, academics, and the progress of corporate citizenship. Business and Society Review, 109, 5-42. 
Waldman, D. A., Siegel, D. S., \& Javidan, M. (2006). Components of CEO transformational leadership and corporate social responsibility. Journal of Management Studies, 43(8), 1703-1725.

Walumbwa, F. O., \& Lawler, J. J. (2003). Building effective organizations: Transformational leadership, collectivist orientation, work-related attitudes and withdrawal behaviours in three emerging economies. International Journal of Human Resource Management, 14(7), 1083-1101.

Wu, L. Z., Kwan, H. K., Yim, F. H. K., Chiu, R. K., \& He, X. (2015). CEO ethical leadership and corporate social responsibility: A moderated mediation model. Journal of Business Ethics, $130(4), 819-831$.

Yukl, G. (2008). How leaders influence organizational effectiveness. The Leadership Quarterly, 19(6), 708-722.

Yukl, G. A. (2002). Leadership in organizations. New York: Prentice Hall.

Zhu, Y., Sun, L. Y., \& Leung, A. S. (2014). Corporate social responsibility, firm reputation, and firm performance: The role of ethical leadership. Asia Pacific Journal of Management, 31(4), $925-$ 947. 